\section{Primary spinal intramedullary lymphoma mimicking ependymoma}

Tomohiko Machiya, MD; Mitsuhiro Yoshita, MD;

Kazuo Iwasa, MD, PhD; and Masahito Yamada, MD, PhD,

Kanazawa, Japan

A 60-year-old woman presented to our hospital with a 1-month history of sensory disturbance in the bilateral lower limbs. Neurologic examination demonstrated reduced vibratory and proprioceptive sensation and mild weakness in the bilateral lower limbs. Cervical MRI disclosed a solid intramedullary mass lesion with contrast enhancement and cord edema at C2-7 levels (figure 1); the radiologic features were highly suggestive of ependymoma. ${ }^{1,2}$ However, methylprednisolone pulse therapy transiently improved her symptoms and reduced the size of the lesion; biopsy of the cord lesion demonstrated diffuse large B-cell lymphoma (figure 2).

1. Bekar A, Cordan T, Evrensel T, Tolnay T. A case of primary spinal intramedullary lymphoma. Surg Neurol 2001;55:261-264.

2. Koeller K, Rosenblum S, Morrison A. Neoplasms of the spinal cord and filum terminale: radiologic-pathologic correlation. Radiographics 2000; 20:1721-1749
Disclosure: The authors report no conflicts of interest.

Address correspondence and reprint requests to Dr. Tomohiko Machiya, Department of Neurology and Neurobiology of Aging, Kanazawa University Graduate School of Medical Science, 13-1 Takaramachi, Kanazawa, 9208640, Japan; e-mail: komanezumi_2@infoseek.jp

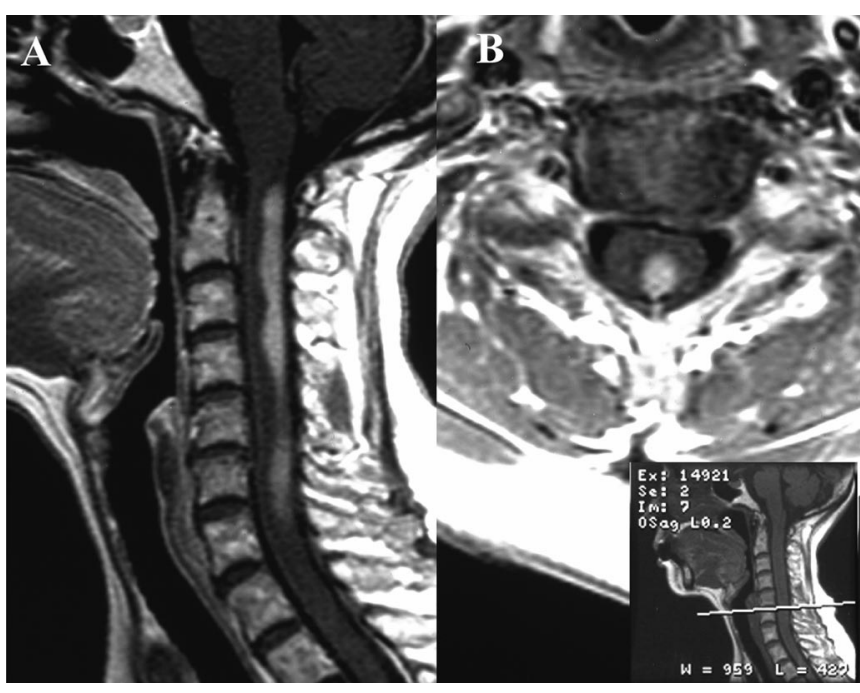

Figure 1. Sagittal (A) and axial T1-weighted MR images (B) of the cervical region with gadolinium enhancement showed a well-demarcated, enhanced, intramedullary lesion in the dorsal column.

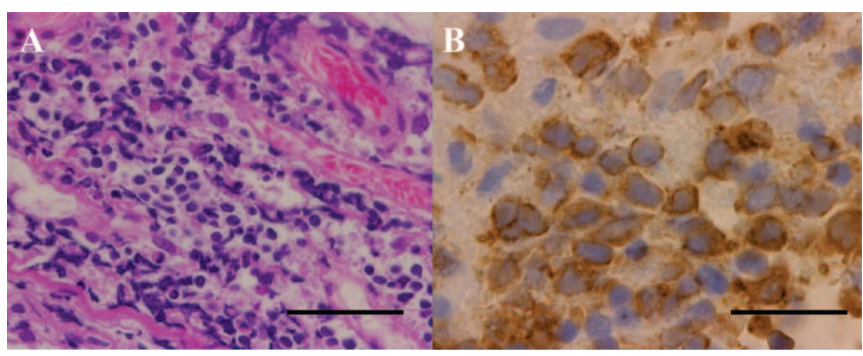

Figure 2. Biopsy of the cord lesion showed infiltration of lymphoma cells (A) with a B cell marker (B). (A:

hematoxylin-eosin, bar $=50 \mu \mathrm{m} ; \mathrm{B}:$ CD79a, bar $=20 \mu \mathrm{m}$.) 


\section{Neurology}

\section{Primary spinal intramedullary lymphoma mimicking ependymoma}

Tomohiko Machiya, Mitsuhiro Yoshita, Kazuo Iwasa, et al. Neurology 2007;68;872

DOI 10.1212/01.wnl.0000257150.31403.61

\section{This information is current as of March 12, 2007}

\section{Updated Information \& Services}

References

Citations

Subspecialty Collections

Permissions \& Licensing

Reprints including high resolution figures, can be found at: http://n.neurology.org/content/68/11/872.full

This article cites 2 articles, 0 of which you can access for free at: http://n.neurology.org/content/68/11/872.full\#ref-list-1

This article has been cited by 1 HighWire-hosted articles: http://n.neurology.org/content/68/11/872.full\#\#otherarticles

This article, along with others on similar topics, appears in the following collection(s):

\section{All Spinal Cord}

http://n.neurology.org/cgi/collection/all_spinal_cord

MRI

http://n.neurology.org/cgi/collection/mri

Spinal cord tumor

http://n.neurology.org/cgi/collection/spinal_cord_tumor

Information about reproducing this article in parts (figures,tables) or in its entirety can be found online at:

http://www.neurology.org/about/about_the_journal\#permissions

Information about ordering reprints can be found online: http://n.neurology.org/subscribers/advertise

Neurology ${ }^{\circledR}$ is the official journal of the American Academy of Neurology. Published continuously since 1951, it is now a weekly with 48 issues per year. Copyright . All rights reserved. Print ISSN: 0028-3878. Online ISSN: 1526-632X.

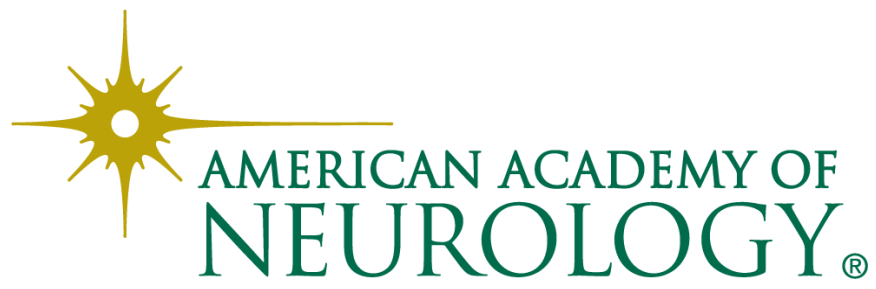

